\title{
Land Use Vulnerability towards the Flood Risk in Surakarta City
}

\author{
Nur Miladan ${ }^{1, *}$, Feira Ariani ${ }^{1}$, Shifa Nurul Indah Pertiwi ${ }^{1}$, Raafi Setiawan ${ }^{1}$, and \\ Kusumaningdyah Nurul Handayani ${ }^{2}$ \\ ${ }^{1}$ Urban and Regional Planning, Faculty of Engineering, Universitas Sebelas Maret, Jalan Ir. Sutami \\ 36 A, Kentingan, Surakarta, 57126, Indonesia \\ ${ }^{2}$ Architecture, Faculty of Engineering, Universitas Sebelas Maret, Jalan Ir. Sutami 36 A, Kentingan, \\ Surakarta, 57126, Indonesia
}

\begin{abstract}
Urban flood risk is one of the frequent disasters in Indonesian cities. It causes the urban vulnerabilities including urban land use, community socio-economic assets, urban infrastructures and buildings. The massive urban land use changes will lead to the increase of flood risk if those changes do not manage properly. In other side, the increase of flood risk is also caused by the land use vulnerability. The assessment of land use vulnerability on flood risk is an important element to identify the urban socio economic losses. Furthermore, the understanding of land use vulnerability could be an essential aspect for the urban land use plans relating to the process of urban planning. This study has purpose to assess the vulnerability of land use on flood risk in Surakarta City. This city has several rivers flowing inside urban areas, and often, the flood occurrences took place due to overflows of those rivers. This research used the deductive approach. The data and information provided by the institutional documents, and field observation. The result of the research indicated that the hazard level has more influence than the land use vulnerability level in the calculation of flood risk. Furthermore, it demonstrated that the land use vulnerability level is not certainly linier correlated to the risk level.
\end{abstract}

\section{Introduction}

The form of land use influences the urban ecological system. In general, the urbanization stimulates the land use changes from non-build-up areas to build-up areas in order to support the urban growth phenomena that are taking place. These changes have an consequence of flood risk increase [1,2]. Nevertheless, flood risk also caused by the urban land use vulnerability $[3,4]$. These situations indicate that the land use and flood risk have a reciprocal correlation in the urban development. The urban planning process needs the assessment of land use vulnerability on the flood risk in order to achieve the urban sustainability. The land use assessment is important element in the urban planning process $[5,6]$.

Corresponding author: nurmiladan@ ft.uns.ac.id 
This research seeks to identify the impacts of flood risk into the urban land use. It is the insight for urban planning process that should accommodate the flood risk existence in the city. The results of the research can be used as a reference to assess the recent spatial planning. The adequate spatial planning should consider the prediction of future flood risk analyzed through the recent empirical situation.

\section{Study area and data}

Surakarta, one of important Javanese cities, having the flood risk is due to the overflows of its river. Its geographical characteristic which is adjacent to Bengawan Solo River, and it is passed by several rivers, such as Bengawan Solo, Pepe, Tanggul, Anyar, etc. flowing inside of the city produce the risk of flooding in urban areas. Nevertheless, the existence of these rivers has the significant influences in the process of urban growth. The high densities of urban areas were growing around of those rivers. In fact, the biggest flooding occurred in 1966, and in recent times, these risks have occurred at least in 2007, 2008 and 2016. These situations become the reasons for selecting Surakarta as the case study for this research.

The area of Surakarta is approximately $44,04 \mathrm{~km} 2$ that cover five districts namely Laweyan, Serengan, Pasarkliwon, Jebres, and Banjarsari. These districts are divided into 51 sub-districts. This city is located approximately +92 from the sea level. Furthermore, the urban settlement is about $65 \%$ of city area.

Table 1. Land use in 2016 (Ha).

\begin{tabular}{|c|c|c|c|c|c|}
\hline District & Laweyan & Serengan & Pasar Kliwon & Jebres & Banjarsari \\
\hline Sub-district & $\begin{array}{c}\text { Sriwedari, } \\
\text { Penumping, } \\
\text { Purwosari, } \\
\text { Kerten, Jajar, } \\
\text { Karangasem, } \\
\text { Pajang, } \\
\text { Sondakan, } \\
\text { Laweyan, } \\
\text { Bumi, } \\
\text { Penularan }\end{array}$ & $\begin{array}{c}\text { Kemlayan, } \\
\text { Kayengan, } \\
\text { Tipes, } \\
\text { Serengan, } \\
\text { Danu- } \\
\text { kusuman, } \\
\text { Joyotakan }\end{array}$ & $\begin{array}{c}\text { Kampung- } \\
\text { baru, Kauman, } \\
\text { Kedung } \\
\text { Lumbu, } \\
\text { Baluwarti, } \\
\text { Gajahan, } \\
\text { Joyosuran, } \\
\text { Semanggi, } \\
\text { PasarKliwon, } \\
\text { Sangkrah } \\
\text { Sewu, Jagalan, } \\
\text { Pucangsawit, } \\
\text { Jebres, } \\
\text { Mojosongo, } \\
\text { Tegalharjo, } \\
\text { Purwadining- } \\
\text { ratan, } \\
\text { Kepatihan } \\
\text { Wetan, } \\
\text { Kepatihan } \\
\text { Kulon }\end{array}$ & $\begin{array}{c}\text { Timuran, } \\
\text { Keprabon, } \\
\text { Ketelan, } \\
\text { Punggawan, } \\
\text { Kestalan, } \\
\text { Setabelan, } \\
\text { Gilingan, } \\
\text { Nusukan, } \\
\text { Kadipiro, } \\
\text { Banyuanyar, } \\
\text { Sumber, } \\
\text { Manahan, } \\
\text { Mangkubumen }\end{array}$ \\
\hline $\begin{array}{c}\text { Settlement } \\
\text { (housing) }\end{array}$ & 567.51 & 230.62 & 310.51 & 726.91 & 1046.59 \\
\hline Service & 102.75 & 19.45 & 49.82 & 153.79 & 65.52 \\
\hline $\begin{array}{c}\text { Establishmen } \\
\text { t//office) }\end{array}$ & 67.9 & 33.23 & 36.48 & 45.38 & 63.58 \\
\hline $\begin{array}{c}\text { Manufacture } \\
\text { (Industry) }\end{array}$ & 39.4 & 6.14 & 7.17 & 27.59 & 17.81 \\
\hline Fallow land & 3.48 & 2.13 & 9.66 & 43.89 & 49.66 \\
\hline Dry land & 0 & 0 & 0 & 57.61 & 40.84 \\
\hline Paddy field & 20.7 & 0 & 0 & 17.1 & 57.59 \\
\hline Cemetery & 6.08 & 1.38 & 1.54 & 31.05 & 28.78 \\
\hline Sport yard & 12.03 & 2.06 & 8.17 & 9.03 & 28.76 \\
\hline City park & 0.25 & 0 & 0 & 8.34 & 3.52 \\
\hline Others & 43.76 & 24.39 & 58.17 & 137.49 & 78.45 \\
\hline Total & 863.86 & 319.4 & 481.52 & 1258.18 & 1481.1 \\
\hline
\end{tabular}

Source: Modification of the land use of Surakarta in 2016, Surakarta Municipality Figures in 2017 [7]. 


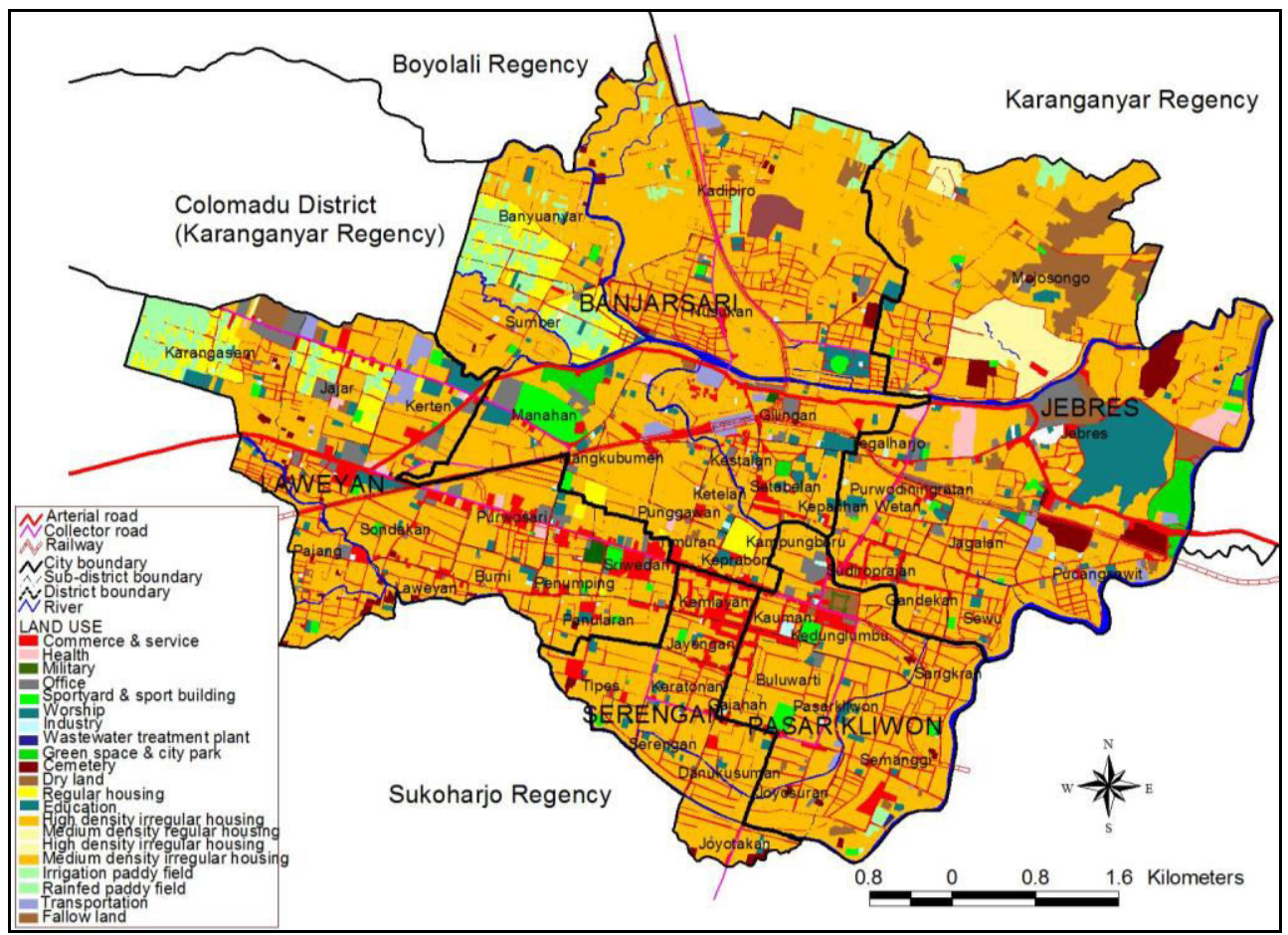

Fig. 1. Land use of study area.

Source: The Modification of the existing land use in Spatial Planning of Surakarta City for 20112031, 2018 [8].

\section{Methodology}

The research used deductive approach, and it used primary and secondary data. The institutional documentations related to the urban spatial planning for 2011-2031, the documentations of urban flood risk, and related urban statistics were used as the main sources. In addition, it also explored with the aerial photographs of Surakarta in 2015. Meanwhile the primary data were carried out through the field observation. It was useful to confirm the analysis being created on the secondary data.

The explanation of land use vulnerability on the flood risk is based on the theoretical perspectives related to the disaster risk. This term defines the summarization of hazard and vulnerability $[9,10,11]$. Hazard relates to the factors causing the damages in a disaster risk, meanwhile vulnerability means the factors being impacted by the hazard during a disaster occurrence. This research used the flood hazard identification based on the institutional documentation that has been provided by the local authority. Equations should be centred and should be numbered with the number on the right-hand side. 


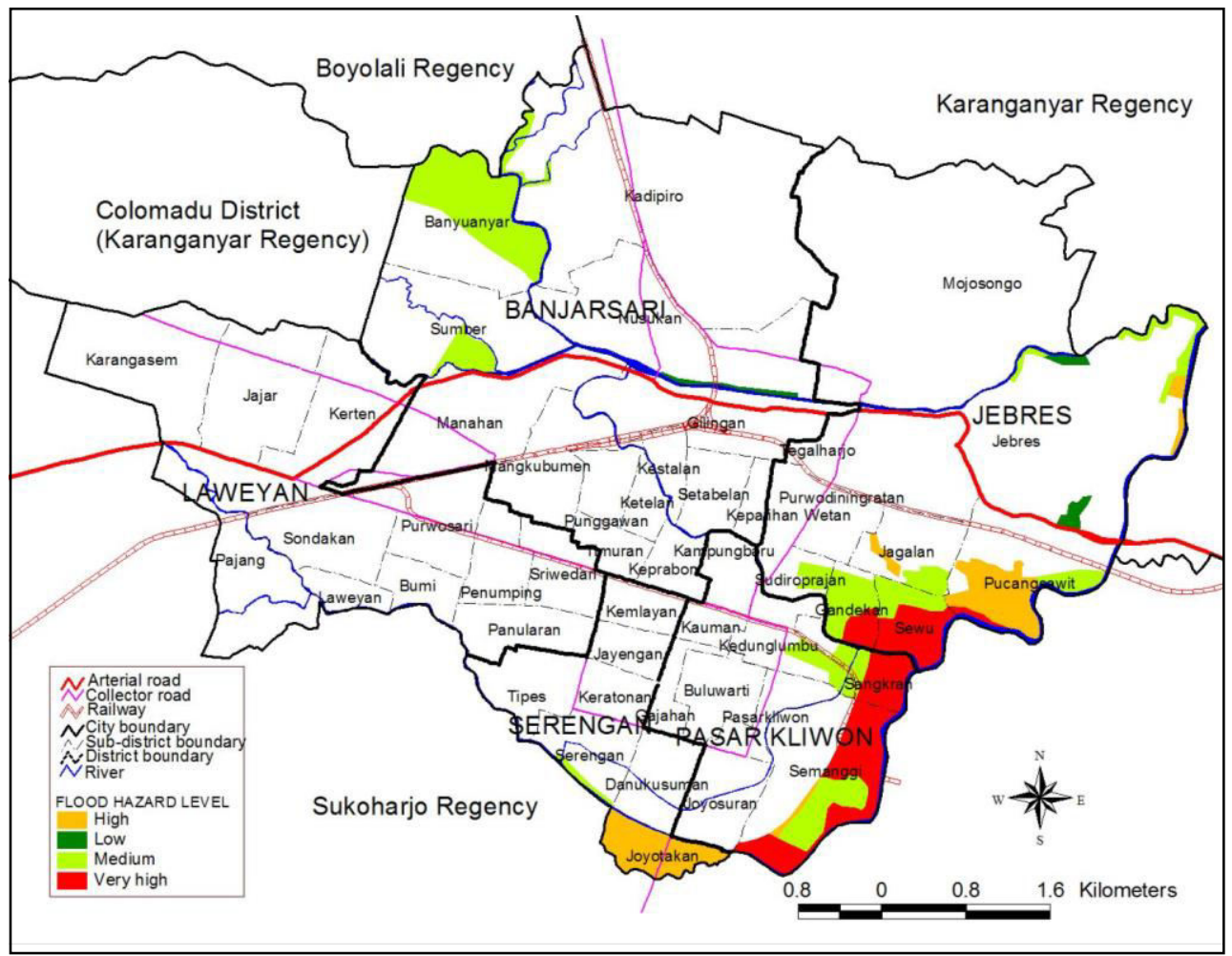

Fig. 2. Flood hazard of Surakarta City.

Source: The Modification of Flood hazard map of Surakarta City in 2014 [12].

The map above was used as the basic data of flood hazard in Surakarta. It is a substantial analysis in the Document of Monitoring of flood and landslide in Surakarta, which was created by the Department of Public Works of Surakarta in 2014. It classifies 4 (four) flood hazard levels including low, medium, high, and very high. The flood hazard classification is based on the land form analysis, and flood characteristics analysis which was provided through Public Participation Geographic Information System (PPGIS). The majority of flood hazard zone is located in the eastern area and southern area of city including several sub-districts: Jebres, Pucangsawit, Jagalan, Sewu, Gandekan, Sangkrah, Semanggi, Joyotakan, Serengan.

Table 2. Flood hazard area of Surakarta City in 2014

\begin{tabular}{|c|c|}
\hline Flood hazard level & Area (ha) \\
\hline Low & 15,99 \\
\hline Medium & 244,01 \\
\hline High & 98,15 \\
\hline Very High & 131,92 \\
\hline Total & 490,07 \\
\hline
\end{tabular}

Source: The Modification of Flood hazard map of Surakarta City in 2014. 
The identification of flood hazard leads to the analysis of flood vulnerability to land use. In this research was conducted by several steps of identification and analysis. These steps include the identification of flood impacted land use, the identification of flood hazard, the analysis of flood vulnerability to land use, and the analysis of flood risk toward land use vulnerability.

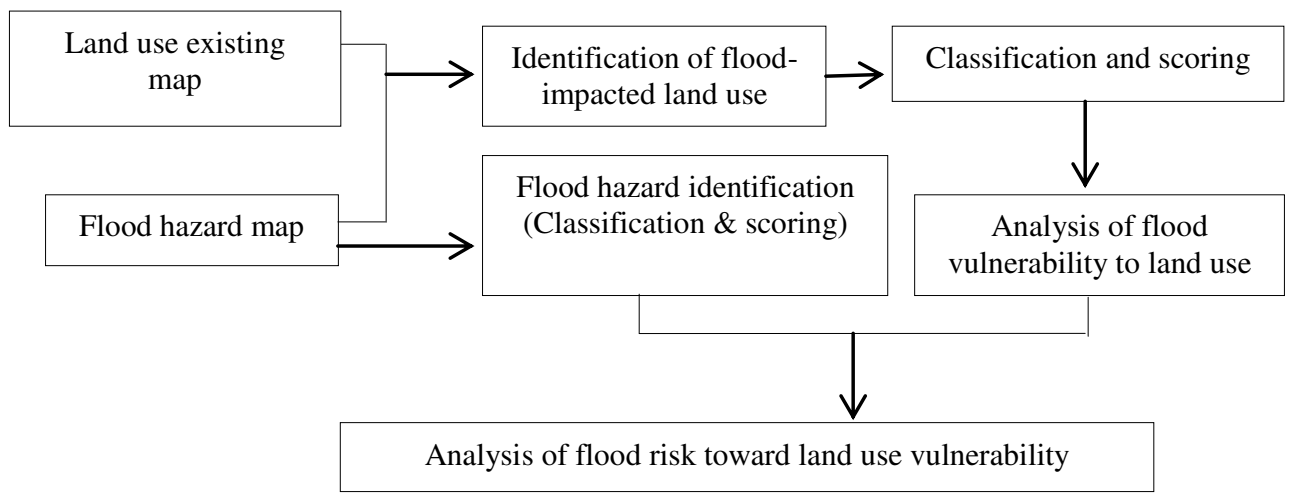

Fig. 3. The assessment steps of the flood risk to land use vulnerability.

Source: Identification, 2018.

The assessment of flood vulnerability to the land use was carried out through the score analysis. The value of vulnerability is based on the density of land use. The high density of build-up area has the consequence of the high level of vulnerability of productive urban land use (housing, commerce and service, office, etc..). Otherwise, the high density of green space produces the low level of vulnerability.

Table 3. The Criteria of flood vulnerability score.

\begin{tabular}{|c|c|c|c|c|c|}
\hline No & Land use & Land use classification & Indicator & Category & Score \\
\hline \multirow{3}{*}{1} & \multirow{3}{*}{$\begin{array}{c}\text { Productive } \\
\text { urban spaces: } \\
\text { housing, } \\
\text { commerce \& } \\
\text { service, office, } \\
\text { urban } \\
\text { facilities, } \\
\text { industry, } \\
\text { transportation, }\end{array}$} & \multirow{3}{*}{$\begin{array}{l}\text { - Housing: Low density, medium } \\
\text { density, high density } \\
\text { - Commerce \& service: traditional, } \\
\text { modern } \\
\text { - Office: public, private } \\
\text { - Urban facilities : education, } \\
\text { worship, health, sport yard \& } \\
\text { buildings, Wastewater treatment } \\
\text { plant } \\
\text { - Industry }\end{array}$} & $\begin{array}{c}<33 \% \text { of area is } \\
\text { flood impacted } \\
\text { zone }\end{array}$ & Low & 1 \\
\hline & & & $\begin{array}{c}33-66 \% \text { of area } \\
\text { is flood impacted } \\
\text { zone }\end{array}$ & Medium & 2 \\
\hline & & & $\begin{array}{c}>66 \% \text { of area is } \\
\text { flood impacted } \\
\text { zone }\end{array}$ & High & 3 \\
\hline \multirow{3}{*}{2} & \multirow{3}{*}{$\begin{array}{c}\text { Non- } \\
\text { productive } \\
\text { urban spaces: } \\
\text { green area, } \\
\text { fallow land, } \\
\text { paddy field, } \\
\text { dry land }\end{array}$} & \multirow{3}{*}{$\begin{array}{l}\text { - Green area : urban park, river } \\
\text { green belt, cemetery } \\
\text { - Fallow land : planned, unplanned } \\
\text { - Paddy field : irrigation, rainfed } \\
\text { - Dry land : agriculture, plantation }\end{array}$} & $\begin{array}{c}>30 \% \text { of area is } \\
\text { flood impacted } \\
\text { zone }\end{array}$ & Low & 1 \\
\hline & & & $\begin{array}{c}15-30 \% \text { of area } \\
\text { is flood impacted } \\
\text { zone }\end{array}$ & Medium & 2 \\
\hline & & & $\begin{array}{c}<15 \% \text { of area is } \\
\text { flood impacted } \\
\text { zone }\end{array}$ & High & 3 \\
\hline
\end{tabular}

Source: Identification, 2018 
The results of flood vulnerability score are summarized, and then it is categorized based on the interval between maximum score and minimum score. The categorization of vulnerability includes very high level, high level, medium level, low level, and no level (zero), and it is divided into the average of intervals. Furthermore, the final calculation of vulnerability is the summarization between the vulnerability categorization of the number of land use classification and the vulnerability categorization of total score. The number of land use classification is also divided into the categorization of vulnerability.

$$
V=V t s+V l c n
$$

Where:

$\mathrm{V}$ is vulnerability of area

Vts is vulnerability based on the categorization of total score

Vlcn is vulnerability based on the categorization of land use classification number

Meanwhile the results of summarization can be explained trough the following matrix (Table 4). It can be used for the calculation of risk being resulted through the hazard categorization $(\mathrm{Hzd})$ and the vulnerability categorization $(\mathrm{V})$.

Table 4. Vulnerability and risk matrix.

\begin{tabular}{|c|c|c|c|c|c|}
\hline $\begin{array}{c}\text { Vts/Vlcn } \\
\text { or } \\
\text { Hzd/V }\end{array}$ & VH & H & M & L & N \\
\hline VH & VH & H & H & M & M \\
\hline $\mathbf{H}$ & H & H & M & M & L \\
\hline $\mathbf{M}$ & H & M & M & L & L \\
\hline L & M & M & L & L & L \\
\hline $\mathbf{N}$ & M & L & L & L & N \\
\hline
\end{tabular}

Source: Identification, 2018.

\section{Result and Discussions}

\subsection{Identification of flood hazard impacted land use}

The classification of flood hazard impacted land use divided into 18 types i.e housing $(\mathrm{H})$, high density irregular housing (HDIH), medium density regular housing (MDRH), arterial road (AR), collector road (CR), irrigation paddy field (IPF), commerce and service (CS), education (E), worship (W), office (O), sport yard and sport building (SSB), health (He), cemetery (C), fallow \& dry land (FDL), railway (R), industry (I), green space (GS), and wastewater treatment plant (WTP). The dominant land use type being affected by the flood hazard is high density irregular housing ( $\pm 366,99$ ha). This land use type is the majority of land use classification in the sub-districts of Surakarta. In addition, the collector road is also the dominant land use type affected by the flood hazard $( \pm 31,38 \mathrm{ha})$.

The flood hazard impacted land use is located in 19 sub-districts. Several sub-districts have the high vulnerability due to its percentage of impacted area, and its various land use classification. The percentage of impacted land use area is comparison between the area of land use type being affected by flood, and the total area of land use type in each subdistrict. For example, the area of flood-impacted housing is compared to the total area of housing in sub-district. Those sub-districts include Banyuanyar, Gandekan, Joyotakan, Pucangsawit, Sangkrah, Semanggi, and Sewu. However, there are several sub-districts 
having the low vulnerability such as Gilingan, Joyosuran, Manahan, Nusukan, and Pasar Kliwon. The description of flood hazard impacted land use can be seen in figure below.

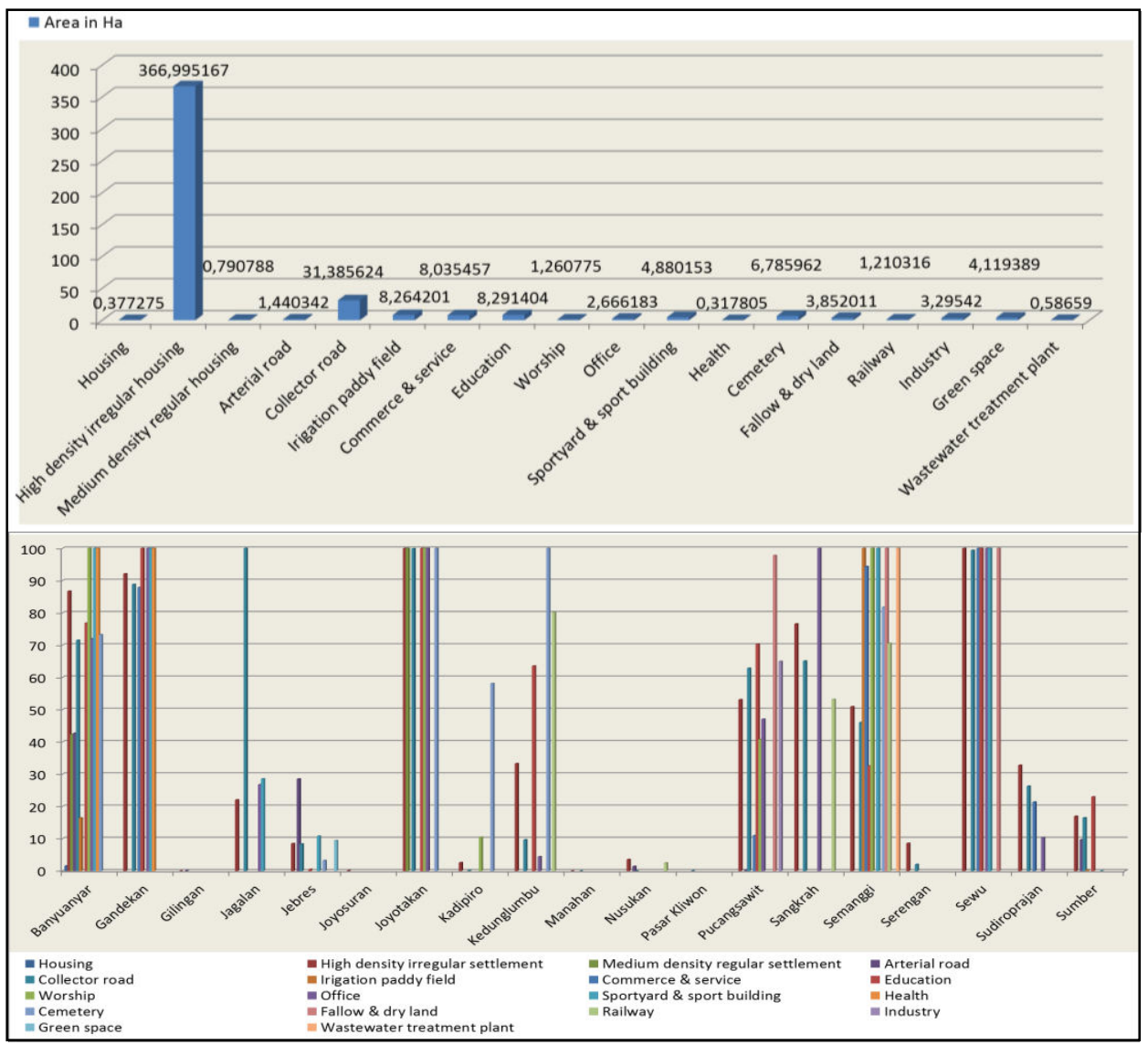

Fig. 4. The existing land use impacted by flood hazard.

Source: Analysis, 2018.

\subsection{The Classification of land use vulnerability on flooding}

The identification of land use vulnerability leads to the assessment of the classification of land use vulnerability. This assessment was carried out through the calculation of transitional matrix of flood vulnerability. This matrix classifies the vulnerability score and the number of land use classification. Banyuanyar is the highest vulnerable sub-district, meanwhile Joyosuran and Pasarkliwon are the lowest vulnerable sub-districts.

However, the vulnerability category is only classified into 3 (three) levels of vulnerability. The high level of vulnerability is located in Banyuanyar Sub-district. Meanwhile Joyotakan, Semanggi, Sewu, Gandekan, Pucangsawit are the sub-districts having the medium level of vulnerability. The low level of vulnerability is located in several sub-districts including Sumber, Jebres, Jagalan, Sudiroprajan, Sangkrah, Kedunglumbu, and Serengan. The description of the vulnerability category can be seen in Figure 5 . 


\begin{tabular}{|c|c|c|c|c|c|c|c|c|c|c|c|c|c|c|c|c|c|c|c|c|}
\hline Sub-district & $\mathbf{H}$ & HDIH & MDRH & $\mathbf{A R}$ & CR & IPF & CS & $E$ & $\mathbf{w}$ & 0 & SSB & $\mathrm{He}$ & C & FDL & $\mathbf{R}$ & $I$ & GS & WTP & TS & LUC \\
\hline Banyuanyar & 1 & 3 & 2 & 2 & 3 & 2 & & 3 & 3 & 3 & 3 & 3 & 1 & & & & & & 29 & 12 \\
\hline Gandekan & & 3 & & & 3 & & 3 & 3 & & 3 & 3 & 3 & & & & & & & 21 & 7 \\
\hline Sewu & & 3 & & & 3 & & 3 & 3 & & 3 & 3 & & & 1 & & & & & 19 & 7 \\
\hline Pucangsawit & & 2 & & 1 & 2 & & 1 & 3 & 2 & 2 & & & & 1 & & 2 & & & 16 & 9 \\
\hline Jebres & & 1 & & 1 & 1 & & & 1 & & & 1 & & 3 & & & & 3 & & 11 & 7 \\
\hline Kedunglumbu & & 2 & & & 1 & & & 2 & & 1 & & & 1 & & 3 & & & & 10 & 6 \\
\hline Jagalan & & 1 & & & 3 & & & & & 1 & 1 & & & & & & & & 6 & 4 \\
\hline Kadipiro & & 1 & & & 1 & & & & 1 & & & & 1 & & & & & & 4 & 4 \\
\hline Nusukan & & 1 & & 1 & 1 & & & & & & & & & & 1 & & & & 4 & 4 \\
\hline Sudiroprajan & & 1 & & & 1 & & 1 & & & 1 & & & & & & & & & 4 & 4 \\
\hline Gilingan & & 1 & & 1 & & & & & & & & & & & & & & & 2 & 2 \\
\hline Manahan & & 1 & & & 1 & & & & & & & & & & & & & & 2 & 2 \\
\hline
\end{tabular}

Note:H: housing; HDIH: high density irregular housing; MDRH: medium density regular housing; AR: arterial road; CR: collector road; IPF: irrigation paddy field; CS: commerce \& service; E: education; W: worship; O: office; SSB: sport yard \& sport buildings; He: Health; C: cemetery; FDL: fallow \& dry land; R: railway; I: industry; GS: green space; WTP: wastewater treatment plant; TS: total score; LUC: land use classification

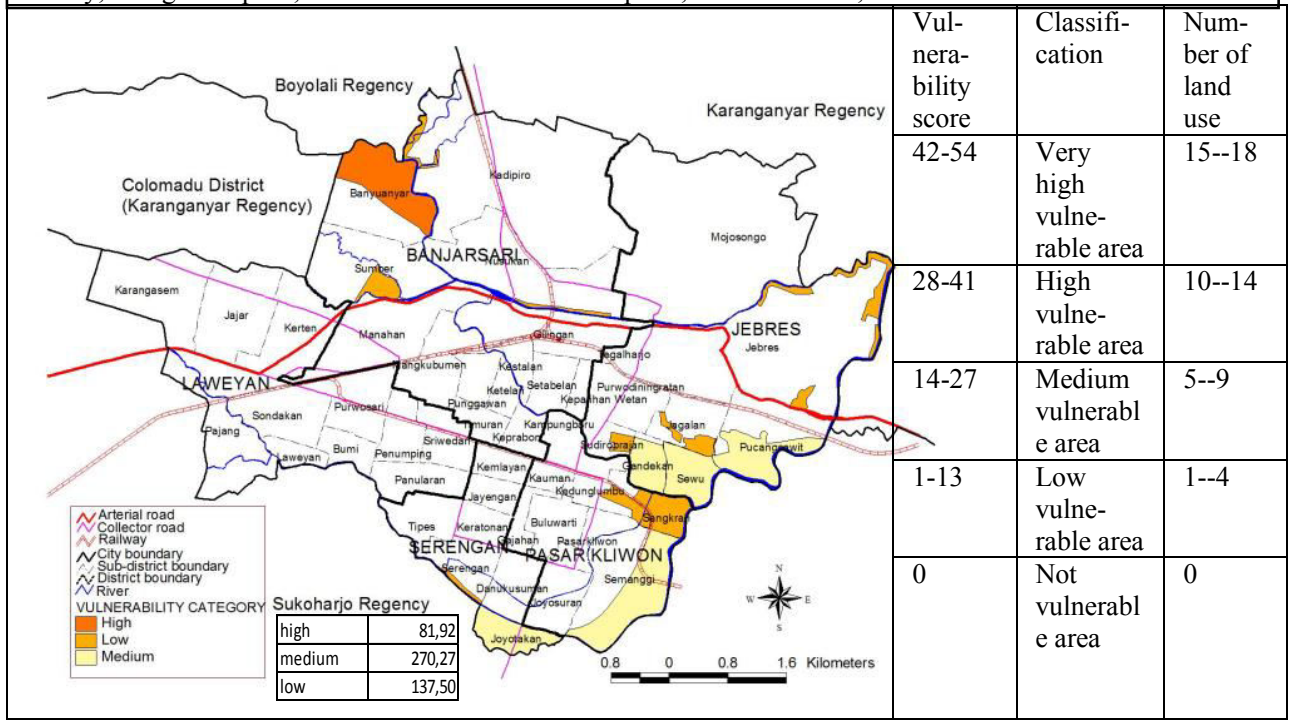

Fig. 5. Land use vulnerability to flooding.

Source: Analysis, 2018.

\subsection{The vulnerability of Land Use on flood risk}

Based on the results of land use vulnerability analysis, 3 (three) categories of vulnerability level were identified. This result is correlated to the hazard identification. The data overlay of vulnerability level and hazard level defines 32 types of flood risk level. There are 7 subdistricts having the various level of flood risk including Gandekan, Jagalan, Jebres, Pucangsawit, Sangkrah, Semanggi, and Sewu. High flood risk remains occur in the eastern part of Surakarta such as Gandekan, Pucangsawit, Semanggi, Sewu. Meanwhile the highest flood risk takes place in Semanggi Sub-district. The high risk occurs due to several districts which have the very high level of hazard, and medium level of vulnerability. The very high level of hazard takes place in the surrounding of main rivers passing Surakarta: Bengawan Solo River and Pepe River. In other side, Banyuanyar Sub-district, having the highest land use vulnerability to flooding, is only threatened by the medium level of flood risk. It is categorized as medium level of flood risk because its hazard classification is only medium level, although it has the high land use vulnerability. However, dominantly Surakarta City 
has the medium level of flood risk. This situation occurs due to the majority of vulnerability classification or hazard classification is also medium level.

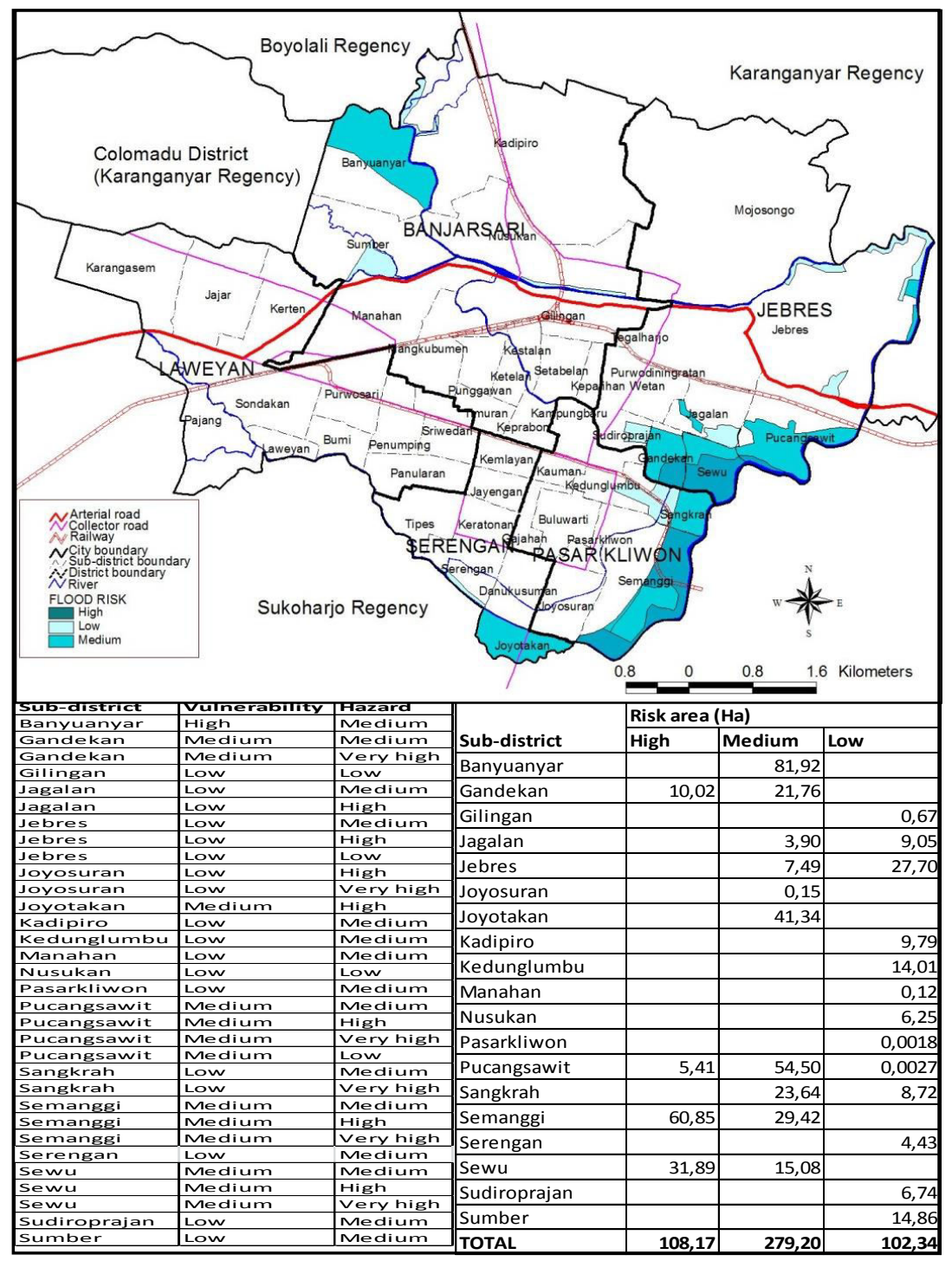

Fig. 6. Flood risk relates to the land use.

Source: Analysis, 2018.

\section{Conclusion and Recommendation}

The assessment of land use vulnerability to flooding was well explored using the calculation of vulnerability score and land use classification. The assessment of land use vulnerability indicates the high-density irregular housing and collector road are the most vulnerable land use on flooding in Surakarta City. Furthermore, the number of land use classification has a linier correlation to the vulnerability score. The classification of land use vulnerability on flooding in Surakarta is divided into the high level (81,92 ha), the medium level (270,27 ha), and the low level (137,50 ha). Nevertheless, the categorization 
of land use vulnerability on flooding is not certainly linier correlated to the categorization of risk. The research demonstrates that the level of hazard has more influence than the level of land use vulnerability for the determination of the flood risk classification. The assessment of flood risk indicates the majority of flood-impacted area has the medium level of risk $(279,20 \mathrm{ha})$. The assessment of land use vulnerability on flooding is important to be implemented because it is useful to support the process of the determination and evaluation of spatial planning. The flood risk management should be also integrated to the adaptive land use on flooding in order that the sustainable city process can be achieved.

\section{Acknowledgments}

The authors would like to thank to the Institute of Research and Community Service, the Department of Urban and Regional Planning, Faculty of Engineering, Universitas Sebelas Maret which has facilitated this research activities.

\section{References}

1. Yoonjeong Lee, Samuel D. Brody 2018 Examining the impact of land use on flood losses in Seoul, Korea,Land Use Policy 70500-509

2. Jie Liu, Zhen-wu Shi 2017 Quantifying land-use change impacts on the dynamic evolution of flood vulnerability,Land Use Policy 65198-210

3. Mwazvita T.B. Dalu, Charles M. Shackleton, Tatenda Dalu 2018 Influence of land cover, proximity to streams and household topographical location on flooding impact in informal settlements in the Eastern Cape, South Africa, International Journal of Disaster Risk Reduction 28 481-490

4. Eui Hoon Lee, Joong Hoon Kim 2018 Development of a flood-damage-based flood forecasting technique, Journal of Hydrology 563 181-194

5. Dan Yu, Ping Xie, Xiaohua Dong, Bob Su, Xiaonong Hu, Kai Wang, Shijin Xu 2018 The development of land use planning scenarios based on land suitability and its influences on eco-hydrological responses in the upstream of the Huaihe River basin, Ecological Modelling, 373 53-67

6. Anna M. Hersperger, Eduardo Oliveira, Sofia Pagliarin, Gaëtan Palka, Peter Verburg, Janine Bolliger, Simona Grădinaru 2018 Urban land-use change: The role of strategic spatial planning, Global Environmental Change 51 32-42

7. Statistics of Surakarta Municipality 2017 Surakarta Municipality in Figures 2017

8. Development Planning Agency (BAPPEDA) 2011 Spatial Planning of Surakarta City for 2011-2031

9. Susan L. Cutter, Lindsey Barnes, Melissa Berry, Christopher Burton, Elijah Evans, Eric Tate, Jennifer Webb 2008 A place-based model for understanding community resilience to natural disasters, Global Environmental Change 18 598-606

10. Cardona, O.D., M.K. van Aalst, J. Birkmann, M. Fordham, G. McGregor, R. Perez, R.S. Pulwarty, E.L.F. Schipper, and B.T. Sinh 2012 Determinants of risk: exposure and vulnerability. In: Managing the Risks of Extreme Events and Disasters to Advance Climate Change Adaptation [Field, C.B., V. Barros, T.F. Stocker, D. Qin, D.J. Dokken, K.L. Ebi, M.D. Mastrandrea, K.J. Mach, G.-K. Plattner, S.K. Allen, M. Tignor, and P.M. Midgley (eds.)]. A Special Report of Working Groups I and II of the Intergovernmental Panel on Climate Change (IPCC). Cambridge University Press, Cambridge, UK, and New York, NY, USA, pp. 65-108. 
11. Adger, W.N. 2006 Vulnerability, Global Environmental Change 16 268-281

12. Department of Public Works of Surakarta City 2014 Monitoring of flood and landslide in Surakarta City in 2014 